\title{
Attitudes toward Homosexuality among Indonesian Social Work College Students
}

\author{
Binahayati Rusyidi \\ Social Welfare Department, Universitas Padjadjaran, Indonesia \\ E-mail: binahayati@unpad.ac.id \\ MD.Kamrujjaman \\ Graduate Social Welfare Program, Universitas Padjadjaran, Indonesia \\ E-mail: kamrujjaman.sust012@gmail.com
}

\begin{abstract}
This study investigated the associations of sociodemographic and socio-culture factors with attitudes toward homosexuality. Using convenience sampling, students were recruited from 5 social work programs at 5 (five) different universities in provinces of West Java, Yogyakarta, East Java and Maluku. Attitudes toward homosexuality were measured using revised version of Attitudes toward Lesbians and Gay Men Scale. Simple regression analysis was performed to examine the associations. Five hundred and eleven undergraduate students aged between 17 to 28 years completed self-administered survey conducted in late 2016. The study found that social work student' generally indicated negative attitudes toward homosexuality. Levels of interaction with homosexual individuals and length of study associated with attitudes toward homosexuality. Higher levels of interactions with homosexuals associated with more positive attitudes toward homosexuality. On the contrary, students from older cohort reported more negative attitudes toward homosexuality than their younger counterparts. Sex, ethnicity, religion and the level of religiosity were not found as significant factors. The findings bring some implications for reviewing social work education and further studies.
\end{abstract}

Keywords: attitudes toward homosexuality, Muslim society, social prejudice, social work students.

\section{INTRODUCTION}

There has been great varieties with regards to societal attitudes toward homosexuality that brings different impacts on homosexuals' welfare. In most developed Western countries, public attitudes toward homosexuality have improved over time. This is partly indicated by the declining of homophobic attitudes in one side and the increasing of tolerance toward same-sex marriage or homosexual parenting in the other side. Nevertheless, in many other developing South region, the society remains express negative attitudes where homosexuality is strongly rejected and criminalized [1], [3] so that gay men, lesbian women, bisexuals and transgender can face harsh discrimination, oppression, violence and punishment. Such unequal and harsh treatments combined with lack of services are risk factors that negatively affect safety, employment opportunities, coping skills, mental health, and general welfare this sexual minority group [4], [8].
Social work is one of professions who are in contact with homosexuals and their significant others through various practice settings. Social workers are agents to promote social justice so that homosexuals' rights are acknowledged, respected and fulfilled. Ruling by its ethical principle, social workers are responsible to challenge social injustice experienced by marginalized or oppressed groups including gays and lesbians. Studies have reported attitudes held by social workers can influence their delivery of services [6], [7]. Therefore, it is important for social workers to be critical of their own attitudes toward homosexuals, take actions to reduce public prejudice against homosexuals and master competent practices with diverse groups so that they can deliver effective and professional services. Social work education can play important roles to prepare social workers working effectively with this sexual minority groups [2], [3], [15], [17], [19].

This study explored the attitudes of Indonesian undergraduate social work students' toward homosexuality and factors associated with such attitudes. So far only one study conducted more than 20 years ago about attitudes of undergraduate students of agricultural study in Indonesia [10] so that this study can be considered the first to be conducted among Indonesian social work students. It is expected that the study can reduce the gap of knowledge by presenting evidence from a developing and predominantly Muslim country where homosexuality is strongly rejected. The study is also expected to provide recommendations for Indonesian social work curriculum to deal with issues of diversity.

\section{METHODS}

The participants of the study were social work students from 5 (five) different universities located in the provinces of West Java (2 universities), East Java, Yogyakarta, and Maluku. Those universities were selected not only because they agreed to be involved in the study but also in order to represent the varieties of social work education in Indonesia with regards to the type, its affiliation, and management. Of those universities, two were private and the other three were public universities. Three participating universities are considered as secular while the other two have affiliation with Islam and Christian ideology of teaching. Four universities are administered by the 
Ministry of Research, Technology and Higher Education whereas one is run under the Ministry of Religion Affairs.

The process of the study was divided into several phases. Firstly, researchers contacted the head of social department at every university to get approval for collecting the data from their students. Secondly, lecturers who were scheduled to teach at odd semester of 2016 were identified, asked for assistance and given descriptions about the study. Research member then mailed packet of questionnaires to each identified lecturers and asked them to distribute the questionnaires within the first 3 weeks of semester. The questionnaires were filled by student in classes as soon as they were distributed by the lecturers.

Informed consent page that explained study's purposes, research's principals and her contact number, participant' anonymousness, and protection of confidentiality was attached at each questionnaire. The lecturers were not allowed to be in class when participants filled in the questionnaires to reduce pressure and bias. When the surveys were completed, the lecturers put all questionnaires into sealed envelopes and mailed them back to research principle. There was no incentive provided for both students and lecturers involving in the study but research report was provided for each university upon request. Qualitative data through telephone interviews were also obtained from the head of departments regarding the curriculum and learning processes. Five hundred twenty seven students participated in the study but only 511 provided completed responses and were included in data analysis.

The study utilized both validated and self-developed instruments. All validated instruments are delivered in English and for this study they all were translated into Bahasa Indonesia. Attitudes toward Lesbians and Gay Men Scale Revised Short Version were used to measure students' attitudes toward homosexuality. This Scale is the revised version of Herek's Attitudes toward Lesbians and Gay Scale, has high reliability, and it has been validated in many studies. The short version consists of 10 items and is divided into 2 subscales which are Attitudes toward Lesbian subscale and Attitudes toward Gay Men sub-scale. The response is measured using-point scale where $1=$ strongly disagree, $3=$ neutral, and $5=$ agree strongly. The scoring of some items are reversed. Greater score means greater rejection toward homosexuals [9], [11]. In this study the scale was modified so that no statement was used to differentiate lesbians from gay men. For example, instead using statement Ï think male homosexuals are disgusting", the statement was changed as Ï think gay men and lesbians women are disgusting". Similarly, original statement Ï thinks lesbians can't fit into our society was changed as Ï think lesbians and gay men cannot fit into our society". The differentiation was not used because in Indonesia society tends to have strong prejudice against both lesbians and gay men. The internal consistency for this scale was 0.60 , which is at moderate level.

Other instrument was Haj-Yahia religiousity scale used to assess participants' level of religiosity. The scale consists of 3 (three) items and responses to the items were based on a 6-point Likert-type scale in which $1=$ never/not at all and $6=$ very much. Higher score equals to high level of religiosity whereas low scores equal to low level of religiosity. The scale has been used in several studies with population from various religious affiliation in Middle East countries (sia including Indonesia [16]. In this study the reliability of the scale was 75 .

Participants also were asked to provide some basic data including age, sex, religion, ethnicity, and length of study. Sex was measured as a binary variable where $1=$ female, $0=$ male. Religion was assessed through an open question but then it was recoded as binary variable where $1=$ Muslim and $0=$ non-Muslim. Similarly, ethnicity was identified through an open question but later on $t$ was recoded as binary variable where $1=$ bilateral oriented ethnic group and $0=$ patrilineal and matrilineal oriented ethnic group. Meanwhile, age was treated as a continuous variable. The length of study was recoded into two groups: $3^{\text {rd }}$ year and above/junior and senior $(=1)$ and $2^{\text {nd }}$ year and below/freshmen and sophomore $(=0)$. Extent of interaction with homosexuals by asking students to select the degree of their interaction with gays or lesbians that ranges from never (1) to most of the time (5) and this variable was regarded as continuous variable. Data analysis applied both descriptive statistics and simple multiple regressions. Preregressions applied before conducting multiple regressions indicated that all assumptions of linearity were met.

\section{DISCUSSIONS AND RESULTS}

Five hundred and eleven students who completed the survey aged between 17 to 28 years old with average 19.5 years. They originated from 5 (five) universities and their number was quite evenly distributed: Universitas Padjadjaran (19.56\%), Universitas Kristen Maluku (19.17\%), Universitas Pasundan (19.96\%), Univeristas Islam Negeri Yogyakarta $(20.70 \%)$ and Universitas Jember (20.50\%). Fifty-five percent respondents were females and $45 \%$ were males. Ninety percent of participants were Muslim while the rest affiliated with Protestant, Catholic and Buddhism. Because religion affiliation was very disproportionately distributed, this variable was excluded from analysis. The ethnic background of the respondents was vary in which $42 \%$ were Javanese, $28 \%$ Sundanese, $15 \%$ Ambonese, and others $13 \%$. Participants came from different cohorts: first year (33.6\%), second year (30.1\%), third year (29.2\%), and fourth year and above $(7.1 \%)$. Sixty-one percent students never had contact with gays/lesbians and the remaining students ever had different degrees of interaction with homosexuals.

Students' attitudes toward homosexuality were described on table 1 below. In general, attitudes reported by students fell within the range of negative attitudes toward homosexuality $(\mathrm{M}=36.818, \mathrm{SD}=4.07)$. For example, almost $80 \%$ agreed that homosexuals are disgusting, $77 \%$ perceived homosexuals as a sin, three-fourth viewed same-sex intimate relations as wrong and that homosexuals cannot fit into Indonesian society, and more than $65 \%$ considered homosexuals as sick individuals. Although limited, 
interestingly, $63 \%$ thought that homosexuality is not a problem except if society constructed it otherwise. Slightly more than 50\% students also viewed that laws against homosexuality should be lifted up.

The researchers indicated patterns from the above findings. First, to a large extent, the students commonly viewed gays and lesbians as those who expressed deviant behaviour that are against religious and social norms. Homosexuality is also considered as pathological phenomena that needs to be fixed. Such negative attitude tendency reported by large number of Indonesian social workers appears to be in line with findings reported from existing studies in Asia and African like South Korea [12], [14]. In South Korea' study for example, more than $3 / 4^{\text {th }}$ of social work students' attitudes was considered as reflecting homophobia. However at the same time different views started to emerge when some Indonesian students perceived that institutional discrimination against homosexuals was unacceptable and that societal construction over the issue is power related.

In researchers' view, these two patterns may reflect the influences of two type of different environment experienced by the students. In one hand, students are impacted by social-political structures of Indonesian contexts that is highly affected by strong religions and collective views against homosexuality [1]. On the other hand, to a lesser degree, some students are probably start getting the influences from other kind of environment that exposed them to the ideas about social justice and protection of rights for the discriminated groups. Although being more strongly opposed by conservative religious groups, LGBT activists in Indonesia have been being more politically active to express their demands for equal treatment in society. In addition, Indonesia does not have any law that protects LGBTs from discrimination.
Table 1. Frequency of Distribution Attitudes of Indonesian Social Work Students toward Homosexuality $(N=511)$

\begin{tabular}{|c|c|c|c|c|c|c|c|}
\hline Statement & $\mathrm{M}$ & SD & $\begin{array}{l}\text { Disa } \\
\text { gree } \\
\text { Stro } \\
\text { ngly }\end{array}$ & $\begin{array}{l}\text { Disagr } \\
\text { ee } \\
\text { Some } \\
\text { what }\end{array}$ & $\begin{array}{l}\text { Neu } \\
\text { tral }\end{array}$ & $\begin{array}{l}\text { Agree } \\
\text { Some } \\
\text { what }\end{array}$ & $\begin{array}{c}\text { Agree } \\
\text { Strongl } \\
y\end{array}$ \\
\hline $\begin{array}{l}\text { Male/female } \\
\text { homosexuals are } \\
\text { disgusting }\end{array}$ & 4.57 & .931 & 1.8 & 4.1 & 7.4 & 9.2 & 77.1 \\
\hline $\begin{array}{l}\text { Male/female } \\
\text { homosexuality is a } \\
\text { perversion }\end{array}$ & 4.27 & 1.03 & 4.7 & 4.1 & 13.5 & 14.9 & 62.6 \\
\hline $\begin{array}{l}\text { Male/female } \\
\text { homosexual is natural } \\
\text { expression of sexuality } \\
\text { in men/women* }\end{array}$ & 2.78 & 1.51 & 7.7 & 20.4 & 14.5 & 17.2 & 30.2 \\
\hline $\begin{array}{l}\text { Sex between two men } \\
\text { or women is just plain } \\
\text { wrong }\end{array}$ & 4.41 & 1.4 & 5.3 & 4.1 & 9.2 & 7.3 & 74.1 \\
\hline $\begin{array}{l}\text { Male/female } \\
\text { homosexuality is } \\
\text { merely a different kind } \\
\text { of lifestyle that should } \\
\text { not be condemned* }\end{array}$ & 2.77 & 1.50 & 16.2 & 20.4 & 18.8 & 13.9 & 30.7 \\
\hline $\begin{array}{l}\text { Gays/lesbians just } \\
\text { cannot fit into our } \\
\text { society }\end{array}$ & 4.46 & 1.00 & 4.1 & 2.8 & 10.4 & 8.7 & 74 \\
\hline $\begin{array}{l}\text { State laws against } \\
\text { private sexual } \\
\text { behaviour consenting } \\
\text { adult between } \\
\text { women/men should be } \\
\text { abolished* }\end{array}$ & 2.60 & 1.63 & 21 & 17.1 & 10.6 & 10.4 & 40.7 \\
\hline $\begin{array}{l}\text { Male/female } \\
\text { homosexuality is a sin }\end{array}$ & 4.57 & .961 & 3.1 & 2.3 & 8.0 & 7.0 & 79.5 \\
\hline $\begin{array}{l}\text { Male/female } \\
\text { homosexual is no } \\
\text { problem unless society } \\
\text { makes it a problem }\end{array}$ & 2.10 & 1.60 & 16.9 & 8.6 & 4.9 & 6.5 & 63.1 \\
\hline Gays/lesbians are sick & 4.33 & 1.11 & 4.1 & 5.3 & 10.2 & 13.9 & 66.4 \\
\hline
\end{tabular}

DS=Disagree Strongly, DSo=Disagree Somewhat, ASo=Agree Somewhat, AS=Agree Strongly

As indicated in table 2 below, multiple regressions applied to examine factors associated with attitudes toward homosexuality found two significant predictors: level of interaction with homosexuals and length of study. When other predictors were controlled, students with higher degree of interaction with gays and lesbians reported more positive attitudes toward homosexuality than their counterparts who had none or very limited association with gays/lesbians. Level of interaction with homosexuals was the strongest predictor $(p<.001)$. Furthermore, when other independent variables were held the same, students from older cohort (junior \&senior years) expressed more negative attitudes toward homosexuality than those in younger cohort $(\mathrm{p}<.010)$. Independent variables included in the model explained 63 percent of variance. 
Table 2. Regression Attitudes of Indonesian Social Work Students toward Homosexuality on Socio-Demographic and Socio-Cultural Related Variables $(N=511)$

\begin{tabular}{|c|c|c|c|c|c|}
\hline Model & $\begin{array}{l}\text { Unstandard- } \\
\text { ized B }\end{array}$ & $\begin{array}{l}\text { Coeffi- } \\
\text { lcients } \\
\text { Std. } \\
\text { Error }\end{array}$ & $\begin{array}{l}\text { Standa } \\
\text { rdized } \\
\text { Coeffi } \\
\text { cients } \\
\text { Beta }\end{array}$ & $\mathrm{t}$ & Sig. \\
\hline Constant & 22.899 & 1.834 & & 12.487 & .000 \\
\hline $\begin{array}{l}\text { Year of study }\left(3^{\text {rd }}\right. \\
\text { year } \& \text { above }=1)\end{array}$ & 1.252 & .470 & .120 & 2.663 & .008 \\
\hline Sex $($ female $=1)$ & -.472 & .459 & -.047 & -1.028 & .304 \\
\hline $\begin{array}{l}\text { Religion (Islam=1; } \\
\text { non-Islam=0) }\end{array}$ & .138 & .939 & .007 & .147 & .883 \\
\hline $\begin{array}{l}\text { Ethnic group } \\
\text { (patriarchal } \\
\text { oriented=1) }\end{array}$ & -1.258 & .658 & -.096 & -1.910 & .057 \\
\hline $\begin{array}{l}\text { Degree of interaction } \\
\text { with homosexuals }\end{array}$ & -1.122 & .296 & -.171 & -3.788 & .000 \\
\hline Religiosity & .052 & .104 & -.023 & .502 & .616 \\
\hline
\end{tabular}

The influence of interaction level with homosexuals on attitudes toward homosexuality found in this study is consistent with findings in previous cross-cultural studies. Individuals who reported more contact and positive experiences with lesbians and gay men have consistently expressed greater acceptance of homosexuals [12], [15], [18]. One other important finding from this study is the association between the lengths of study with attitudes toward homosexuality. Existing studies have reported inconsistent association between the two variables. For example, [19] found that greater acceptance toward homosexuality were more likely to be reported by students in older cohorts meanwhile [13] found no association at all. One reason that could explain such inconsistency may related with the research context. Tolar's study was conducted in the USA where LGBT issues have been integrated into curriculum and the public attitudes have been more supportive toward homosexuality. There is a possibility that students in older cohort in the USA are getting more liberalized through such educational processes. On the contrary, the issue of LGBT is very new at educational and public settings in Indonesia so that students from older cohort might receive more limited exposure to discourse and discussion of it compared to their younger counterparts.

The findings from this study can bring some implications toward social work education in Indonesia. Negative attitudes toward homosexuality showed by students can have undesired impacts over their practices in the future. They may ignore and stigmatize the existence of the homosexuals and consequently allocate insufficient efforts and attention to help homosexuals to get needed services. The worst case could be that very few social workers really wanted to work with this minority group. In other words, instead of reducing prejudice, social workers become agents that perpetuate discrimination against homosexuals.

According to heads or lecturers of social welfare departments participating in this study, there is neither course on homosexuality or LGBT is offered to the students nor is the encouragement from Indonesian Social Work Education to do so. The issue is limitedly discussed in class depending on the interests of individual lecturers ad there is no standard on the discussed topic. Some discussions might be delivered in a pathological, stereotyped and blaming lenses while some others might be taught in a more liberal and non-punitive ways. There is a common fear among many lecturers to discuss the issue because they do not wanted to be seen as 'promoting homosexuality' or "accepting LGBT" which is against their personal values.

Despite those facts, the study suggests that when there is need to discuss about LGBT in academic setting, it should be conducted in a more objective and non-punitive ways. The issues should be framed within human rights and social justice values that underlie the professional practice rather than morality based. LGBT as individuals and groups have the same as other groups to be treated without discrimination and violence. Excluding or discriminating LGBT them from receiving social work professional services as needed means the violation of their rights. The study found that almost $40 \%$ of social work students ever interacted with homosexuals and more interaction significantly associated with less intolerance toward homosexual. It will be impossible to encourage students to interact more with homosexuals but a positive attitude toward them could be promoted through education. Students and lecturers need to understand that taking a side to reduce discrimination against homosexuals is not equal with encouraging others to be homosexuals. The students and lecturers may need to get more education about this group of people.

There are some limitations of this study. First is the convenience sampling applied in the study that reduces its generalization. The inclusion of independent variables in the study has explained a great degree of variance but it can be developed stronger by taking into account other variables such as attitudes toward gender role which is validated by many studies to have significant impacts on the attitudes toward homosexuality. Further studies can consider using a more rigorous sampling techniques and comprehensive theoretical framework. The universities included in this study was predominantly in Java, therefore next study should consider involving more universities outside Java. It is also important to study the perceptions of social work lecturers and social workers about the issue so that more knowledge can be developed about homosexuality in education and practice settings.

\section{CONCLUSIONS}

In general, Indonesian undergraduate social work students reported negative attitudes toward homosexuality. Unfriendly social environment and unsupportive educational setting against homosexuality are likely to put great impact in shaping student attitudes. This study validates the predictor of attitudes as reported in other cross-cultural studies and found another predictor that is explainable in Indonesian context. Social work education institutions in Indonesia need to be more open-minded about the issue and deal with it properly through educational interventions so that the students are 
better equipped in dealing with sexual minority groups later on in their future career.

\section{REFERENCES}

[1] Adamczyk, A. \& Pitt, C. (2009). Shaping attitudes about homosexuality: The Role of religion and cultural context. Social Science Research, 38(2), 338-351.

[2] Ben-Ari, A.T. (1998). An experiential attitude change: Social work students and homosexuality. Journal of Homosexuality, 36(2), 59-71.

[3] Camilleri, P. \& Ryan, M. (2007). Social work students' attitudes toward homosexuality and their knowledge and attitudes toward homosexual parenting as an alternative family unit: An Australia study. Social Work Education, 25 (3), 288304.

[4] Center for Disease Control and Prevention. Lesbian, Gay, Bisexual and Transgender. (June 21 2017). https://www.cdc.gov/lgbthealth

[5] Cochran, B.N., Stewart, A.J., Ginzler, J.A., \& Cauce, A.M. (2002). Challenges faced by homeless sexual minorities: Comparison of gay, lesbian, bisexual, and transgender homeless adolescent with their heterosexual counterparts. American Journal of Public Health, 92(5): 773-777.

[6] Crisp, C. (2006). Correlates of homophobia and use of gay affirmative practice among social workers. Social Work, 42(4), 319-332.

[7] Faria, G. (1997). The Challenge of health care social worker with gay men and lesbians. Social Work in Health Care, 25 (1/2), 65-72.

[8] Hequembourg, A.L. \& Brallier, S.A. (2009). An exploration of sexual minority stress across the lines of gender and sexual identity. Journal of Homosexuality, 56(3), 273-298. [9] Herek, G.M. (1994). The Attitudes Toward Lesbians and Gay Men Scale. Retrieved from http://lgbpsychology.com/html/atlgfile/pdf on May 12, 2016.

[10] Kyes, K.B. \& Tumbelaka, L. (1994). Comparison of Indonesia and America college students' attitudes toward homosexuality. Psychological Reports, 74, 227-237.

[11] La Rubia, J.M. \& de la O, A.V. (2014). Measurement of attitudes toward lesbians and gay men in students of health sciences from Northeast Mexico. Journal of Behaviour, Health and Social Issues, 6(1), 51-65.

[12] Lim, H.S. \& Johnson, M.M. (2001). Korean social work students' attitudes toward homosexuality. Journal of Social Work Education, 17 (3), 545-554.

[13] Logie, C., Bridge, T.J., \& Bridge, P.D. (2007). Evaluating the phobias, attitudes and cultural competence of master social work students toward the LGBT population. Journal of Homosexuality, 53(4), 201-221.

[14] Matthews, J.D., Clemons, K., \& Avery, L.C. (2017). Social Work students' attitudes toward gay men and lesbian in Namibia. South African Journal of Higher Education, 31 (4), 286-301.

[15] O'Hare, T. \& Williams, C.I. (1996). Fear of AIDS and homophobia: Implications for direct practice and advocacy. Social Work, 41(1): 51-58.
[16] Rusyidi, B., Wulandari, K., Jahidin, A., \& Darwis, R.S. (2017). Definitions of violence against wives among Indonesian social work college students. Journal Sampurasun, $3(1)$.

[17] Ryan, S.D. (2000). Examining social workers' placement recommendations of children with gay and lesbian adoptive parents. Families in Societies, 81(5), 517-528.

[18] Snively, C.A., Kreuger, L., Stretch, J.J., Watt, J.W., \& Chada, J. (2004). Understanding homophobia: Preparing for practice realities in urban and rural settings. Journal of Gay and Lesbian Social Services, 17(1), 59-81.

[19] Tolar, T.C., Lambert, E.G., Ventura, L.A., \& Pasupuleti, S. (2008). The views of social work students toward gay and lesbian persons. Journal of Gay and Lesbian Social Services, $17(3), 59-85$.

[20] Ryan. S.D. (2000). Examining social workers' placement recommendations of children with gay and lesbian adoptive parents. Families in Society, 81 (5), 517-528.

[21] Swank, E. \& Raiz, L. (2010). Attitudes toward gays and lesbians among undergraduate social work students. Affilia, 25(1), 19-29. 